Sebastian Jakubowski

Uniwersytet Wrocławski

sebastian.jakubowski@uwr.edu.pl

\title{
Czasowy całkowity zakaz reklamy otwartego funduszu emerytalnego
}

\author{
JEL Classification: J320, L510, K310
}

Keywords: Pension, Retirement Pension, Social Security, Regulation, Labour Law, Pension Fund, Open-End Pension Funds

\begin{abstract}
Temporary Total Prohibition of Open-end Pension Fund Advertising

The paper discusses the effects of temporary total prohibition of Open-end Pension Fund advertising. This prohibitive regulation was in force in the years 2014-2015 and has raised many controversies, and ultimately became the subject of the Constitutional Court summons. The main thesis of the article is that temporary total prohibition of Open-end Pension Fund advertising has contributed to a decrease in the amount of contributions paid to Open-end Pension Funds and started the process of gradual and informal phasing-out of funded part of pension system in Poland. The scientific method used in this paper is economic analysis of law.
\end{abstract}

\section{Wstęp}

Opracowanie omawia skutki funkcjonowania czasowego całkowitego zakazu reklamy zawierającej informację o otwartych funduszach emerytalnych lub informacje sugerujące, że reklama odnosi się do otwartych funduszy emerytalnych. Zakaz ten obowiązywał w latach 2014-2015 i budził szereg kontrowersji, a w ostateczności stał się przedmiotem skargi do Trybunału Konstytucyjnego. Główną tezą niniejszego artykułu jest twierdzenie, że wprowadzenie czasowego całkowitego zakazu reklamy OFE było niezgodne z Konstytucją, a jego obowiązywanie przyczyniło się do dramatycznego spadku ilości wpłacanych składek do otwartych funduszy emerytalnych i rozpoczęło proces stopniowego i nieformalnego wygaszania kapitałowej części ubezpieczenia emerytalnego. Opracowanie wskazuje również, że czynnikiem, który może zdecydować o dalszym losie rynku 
otwartych funduszy emerytalnych, jest wyrok Trybunału Konstytucyjnego z dnia 4 listopada 2015 r. w sprawie zasad wypłat emerytur ze środków zgromadzonych w otwartych funduszach emerytalnych. Na podstawie tego orzeczenia czasowy całkowity zakaz reklamy OFE został derogowany z systemu prawa, a to daje szansę otwartym funduszom emerytalnym na odbudowę bazy aktywnych członków przekazujących część składki na ubezpieczenie emerytalne OFE i zahamowanie procesu stopniowego i nieformalnego wygaszania kapitałowej części ubezpieczenia emerytalnego. Zastosowana w opracowaniu metoda badawcza to ekonomiczna analiza prawa.

\section{Zniesienie obowiązku przekazywania składek do OFE}

Reforma emerytalna z 2014 roku nałożyła na ubezpieczonych obowiązek zdecydowania o tym, gdzie trafia kapitałowa część ich składki na ubezpieczenie emerytalne. Dotychczasowi członkowie OFE zostali zobowiązani do złożenia deklaracji o dalszym przekazywaniu składek do swoich otwartych funduszy emerytalnych. Zgodnie z art. 11 ustawy nowelizującej z 2013 r. w okresie od 1 kwietnia do 31 lipca 2014 roku każdy członek OFE miał możliwość złożenia do ZUS oświadczenia woli o przekazywaniu części składki emerytalnej do OFE po 1 lipca 2014 roku. Od tej decyzji ubezpieczonego zależało, czy kapitałowa składka jest dzielona na dwie części, między subkonto w ZUS (4,38\% podstawy wymiaru) oraz konto w OFE $(2,92 \% \text { podstawy wymiaru })^{1}$, czy też w całości trafia ona do ZUS i jest zapisywana na indywidualnym subkoncie ubezpieczonego ( $7,3 \%$ podstawy wymiaru). Należy podkreślić, że brak złożenia deklaracji o dalszym przekazywaniu części składki do otwartego funduszu emerytalnego jest równoznaczne ze skierowaniem tej składki w całości na subkonto w ZUS. Przy czym osoby, które nie złożyły oświadczenia o przekazywaniu części składki do otwartego funduszu emerytalnego nadal pozostają członkami OFE, a fundusze zarządzają ich aktywami zgromadzonymi przed 1 lipca 2014 roku do momentu osiągnięcia przez tych ubezpieczonych wieku emerytalnego. Zgodnie z art. 39a ust. 1 ustawy o systemie ubezpieczeń społecznych, począwszy od 2016 r., co 4 lata, w okresie od 1 kwietnia do 31 lipca, każdy członek OFE będzie miał możliwość złożenia do ZUS takiego oświadczenia woli o przekazywaniu części składki emerytalnej do OFE po 1 lipca danego roku (Dz.U. z 2009 r. Nr 205, poz. 1585 ze zm., dalej: ustawa s.u.s.).

Brak obowiązku przekazywania składek do otwartego funduszu emerytalnego oznacza dla najmłodszych ubezpieczonych dobrowolność korzystania z usług OFE. Starsi ubezpieczeni takiego wyboru nie mają, ponieważ zostali już członkami OFE i pozostaną nimi do momentu osiągnięcia wieku emerytalnego. Na-

1 Decyzję o podziale składki ubezpieczony może zmieniać raz na cztery lata. Wyjątkowo raz na dwa lata, tj. w 2014 i 2016 roku.

Ekonomia - Wroclaw Economic Review 22/2 (2016)

(C) for this edition by CNS 
tomiast osoby, które dopiero wkraczają na rynek pracy i nie zostały wcześniej członkami OFE, mają realny wybór co do tego, czy w ramach drugiego filaru emerytalnego odprowadzać składkę tylko na subkonto w ZUS, czy też jednocześnie odprowadzać ją na subkonto w ZUS i do wybranego przez ubezpieczonego OFE (art. 39 ust. 1 ustawy o s.u.s.).

\section{Wprowadzenie czasowego całkowitego zakazu reklamy OFE}

Jednocześnie z dobrowolnością przekazywania składek do otwartego funduszu emerytalnego wprowadzony został czasowy całkowity zakaz reklamy OFE. Należy tutaj omówić kontekst normatywny tego zakazu. Czasowy całkowity zakaz reklamy otwartego funduszu emerytalnego został wprowadzony przez art. 36 ustawy o zmianie niektórych ustaw w związku z określeniem zasad wypłaty emerytur ze środków zgromadzonych w otwartych funduszach emerytalnych (Dz.U. z 2013 r., poz. 1717., dalej: ustawa nowelizująca z 2013 r.). W roku, w którym miały być składane oświadczenia o dalszym przekazywaniu składki do otwartego funduszu emerytalnego, od dnia 1 stycznia do dnia 31 lipca, zakazana była reklama zawierająca informacje o otwartych funduszach emerytalnych lub informacje sugerujące, że reklama odnosi się do otwartych funduszy emerytalnych. Reklamą nie było zamieszczanie na stronie internetowej otwartego funduszu emerytalnego informacji m.in. o wynikach działalności lokacyjnej funduszu, a także o zasadach polityki inwestycyjnej i celu inwestycyjnym funduszu, wraz ze wskaźnikami, do których są porównywane osiągane przez fundusz stopy zwrotu.

Wprowadzenie niniejszego zakazu uzasadniano istotnym wzmocnieniem ochrony interesów ubezpieczonego w sferze dokonywania możliwie najlepszego wyboru co do przystępowania do określonego funduszu emerytalnego lub też podjęcia decyzji o nieprzekazywaniu określonej części składek do OFE (Uzasadnienie projektu ustawy nowelizującej z 2013 r.).

Obawiano się tutaj prowadzenia przez właścicieli powszechnych towarzystw emerytalnych masowych kampanii reklamowych, zwłaszcza w okresach dokonywania wyboru przez ubezpieczonych. Argumentowano, że duży zasięg takich kampanii, koncentracja w krótkim okresie, wykorzystanie szerokiego wachlarza form przekazu, w tym mediów elektronicznych, nie pozwoliłaby ubezpieczonym podjąć racjonalne i optymalne decyzje.

Równocześnie zwolennicy zakazu podnosili, że wraz dopuszczeniem reklamy OFE w okresach dokonywania wyboru przez ubezpieczonych należałoby prowadzić także reklamę opcji wyboru subkonta prowadzonego przez ZUS, i to z taką samą intensywnością, co reklama wszystkich OFE. Miałoby to umożliwiać dokonywanie realnego wyboru przez ubezpieczonych. Prowadzenie działalności reklamowej subkonta wymagałoby zaangażowania znacznych środków finanso- 
wych ze strony Zakładu Ubezpieczeń Społecznych (Wyjaśnienia Sejmu Rzeczypospolitej Polskiej 2014). Tymczasem ZUS nie jest upoważniony do prowadzenia reklamy, a jedynie zobowiązany do popularyzacji wiedzy o ubezpieczeniach społecznych - w tym OFE (na podstawie art. 66 ust. 1 pkt 8 ustawy o s.u.s.). Dlatego też czasowy całkowity zakaz reklamy OFE miał umożliwiać swobodny wybór ubezpieczonemu i wyrównywać szanse OFE i ZUS.

Obawiano się również stosowania przez powszechne towarzystwa emerytalne tzw. reklamy negatywnej negującej zdolność części repartycyjnej systemu emerytalnego do zapewnienia stabilnych i godziwych świadczeń oraz podważającej zaufanie do ZUS. Umożliwiałoby to przekonywanie jak największej liczby ubezpieczonych do dalszej aktywnej partycypacji w części kapitałowej systemu emerytalnego.

Zwolennicy zakazu wskazywali również na fakt, że zwykła ochrona ubezpieczonego (w trybie art. 197 ustawy o ustawy z dnia 28 sierpnia 1997 r. o organizacji i funkcjonowaniu funduszy emerytalnych, Dz.U. z 2013 r., poz 989, dalej: ustawa o o.f.f.e. mogłaby się okazać niewystarczająca w sytuacji prowadzenia intensywnej i masowej kampanii reklamowej w okresach, w których ubezpieczeni będą dokonywać wyboru. Stosowanie przez powszechne towarzystwa emerytalne nierzetelnej i negatywnej reklamy wobec ZUS prowadziłoby do powstania szkód trudnych lub praktycznie niemożliwych do naprawienia (Uzasadnienie projektu ustawy nowelizującej z 2013 r.). Dlatego też czasowy całkowity zakaz reklamy OFE miał zapewniać ubezpieczonym swobodę przy podejmowaniu decyzji, która powinna być wolna od wpływu błędnych danych pojawiających się w reklamach (Pismo Ministra Pracy i Polityki Społecznej 2014).

Zwolennicy zakazu podkreślali również, że całkowity zakaz reklamy OFE ma charakter jedynie czasowy i następuje tylko w newralgicznych okresach wyboru - w czasie, w którym ubezpieczony powinien być chroniony przed dodatkowymi treściami i perswazyjnymi formami przekazu oraz by ubezpieczony miał czas do namysłu, bez narażania go na presje i próby wpłynięcia na jego decyzję. Powoływano się tutaj na negatywne doświadczenia lat poprzednich, gdy kampanie reklamowe prowadzone przez otwarte fundusze emerytalne były bardzo agresywne i podważały (niekoniecznie rozmyślnie) wiarygodność państwowego ubezpieczenia emerytalnego (Wyjaśnienia Sejmu Rzeczypospolitej Polskiej 2014).

Zastosowanie czasowego całkowitego zakazu reklamy nie eliminowało obowiązku rzetelnego informowania przez powszechne towarzystwa emerytalne o sytuacji ich otwartego funduszu emerytalnego. Obowiązek ten miał być możliwością i szansą dla powszechnych towarzystw emerytalnych na komunikowanie się zarówno ze swoimi obecnymi, jak i potencjalnymi członkami.

Pomimo tych argumentów wprowadzenie czasowego całkowitego zakazu reklamy OFE wzbudziło wiele kontrowersji. Podnoszono szereg zarzutów przeciwko temu rozwiązaniu. Ostatecznie ustawa nowelizująca z 2013 r. stała się przedmiotem dwóch skarg. Pierwszą złożył Prezydent Bronisław Komorowski, który podał w wątpliwość legalność przepisów związanych z zakazem inwestowania

Ekonomia - Wroclaw Economic Review 22/2 (2016)

(C) for this edition by CNS 
OFE w obligacje i nakazem tymczasowego inwestowania OFE w akcje. Jednocześnie Prezydent wskazał na niekonstytucyjność całkowitego zakazu reklamy OFE w okresie składania do ZUS oświadczeń woli członków OFE o dalszym przekazywaniu części składki emerytalnej do OFE (Wniosek Prezydenta Rzeczypospolitej Polskiej 2014). Drugą skargę do Trybunału Konstytucyjnego złożyła Rzecznik Praw Obywatelskich prof. Irena Lipowicz. Wskazała ona, że art. 11 ust. 1 i 2 ustawy nowelizującej z 2013 r., nakazujący transfer części środków z OFE do ZUS w odniesieniu do ubezpieczonych urodzonych między 31 grudnia 1948 r. a 1 stycznia 1968 r., którzy dobrowolnie z własnego wyboru stali się członkami OFE, pozostaje w kolizji z konstytucyjną zasadą ochrony zaufania do państwa i prawa oraz stanowi nieproporcjonalne ograniczenie zasady wolności człowieka (Wniosek Rzecznika Praw Obywatelskich 2014).

Pierwszy zarzut stawiany czasowemu całkowitemu zakazowi reklamowania OFE dotyczył naruszenia art. 54 Konstytucji (Dz.U. z 1997 r. Nr 78, poz. 483 ze zm, cyt. dalej: Konstytucja) oznaczający naruszenie wolności słowa, a w szczególności wolności rozpowszechniania informacji. Prezydent RP słusznie wskazywał na brak uzasadnienia dla tak daleko idącego ograniczenia wolności słowa. Tym bardziej, że Rząd nie powołał żadnej z przesłanek dopuszczających ograniczenie praw i wolności wynikających z art. 31 ust. 3 Konstytucji. Reklama OFE jest skierowana prawie wyłącznie do osób dorosłych, podlegających ubezpieczeniu emerytalnemu, odpowiedzialnych i samodzielnie podejmujących życiowe decyzje, a więc osób, które są $\mathrm{w}$ stanie zrozumieć i rzetelnie ocenić prezentowane im w reklamie treści.

Dodatkowo czasowy i całkowity zakaz reklamy OFE został wprowadzony jednocześnie ze zniesieniem obowiązku odprowadzania części składki emerytalnej do OFE. Tak więc w aktualnym stanie prawnym otwarte fundusze emerytalne konkurują już nie tylko między sobą, ale dla swojej działalności muszą w ogóle przekonać ubezpieczonych do korzyści płynących z członkostwa w OFE. Stąd też czasowy i całkowity zakaz reklamy w kluczowych okresach zarówno dla ubezpieczonych, jak i otwartych funduszy emerytalnych był regulacją zbyt rygorystycznie i w sposób nieuzasadniony ograniczającą wolność rozpowszechniania i pozyskiwania informacji. Tym bardziej, że czasowy całkowity zakaz reklamy OFE nie jest konieczny dla zapewnienia bezpieczeństwa państwa lub porządku publicznego, bądź dla ochrony środowiska, zdrowia i moralności publicznej, albo wolności i praw innych osób.

Jednocześnie wskazywano, że czasowy całkowity zakaz reklamy OFE naruszał zasadę wolności działalności gospodarczej zapisaną w art. 22 konstytucji. Zgodnie z nią ograniczenie wolności działalności gospodarczej jest dopuszczalne tylko w drodze ustawy i tylko ze względu na ważny interes publiczny.

Niewątpliwie bezpieczeństwo systemu emerytalnego i przyszłych emerytów stanowi ważny interes publiczny. Tyle, że dopuszczenie prezentacji reklam usług oferowanych przez otwarte fundusze emerytalne nie jest takim zagrożeniem. Fundusze te prowadzą legalną działalność, szczegółowo regulowaną przepisami prawa powszechnie obowiązującego. Co więcej, zaliczone są one w poczet podmio-

Ekonomia - Wroclaw Economic Review 22/2 (2016)

(C) for this edition by CNS 
tów realizujących zadania z zakresu ubezpieczeń społecznych (art. 3 ust. 1 pkt 2 ustawy o s.u.s.). Dlatego też duże wątpliwości musi budzić pogląd, że rzetelna i zgodna z prawem reklama działalności OFE może godzić w bezpieczeństwo systemu emerytalnego i przyszłych emerytów.

\section{Werdykt Trybunału Konstytucyjnego}

Ostatecznie Trybunał Konstytucyjny orzekł, że wprowadzone przez ustawodawcę rozwiązanie całkowitego i czasowego zakazu reklamy dotyczącej otwartych funduszy emerytalnych lub sugerującej, że odnosi się do otwartych funduszy emerytalnych, jest w stanie doprowadzić do zakładanego przez ustawodawcę celu, to jest umożliwienia ubezpieczonym swobodnego i wolnego od zewnętrznej presji wyboru sposobu uczestnictwa w systemie emerytalnym. Samo wyeliminowanie bezpośrednich lub pośrednich zachęt płynących ze środków masowego przekazu, zwłaszcza w dużym natężeniu, uprawdopodabnia uspokojenie debaty publicznej oraz sprawia, że wybór dotyczący uczestnictwa w filarze kapitałowym i ewentualnie członkostwa w konkretnym funduszu zostanie podjęty przez ubezpieczonych po możliwie obiektywnej ocenie sytuacji. Między projektowanym celem ingerencji w wolność wypowiedzi a środkiem ingerencji (tzn. zakazem reklamy) zachodzą więc logiczne i obiektywnie dostrzegalne związki. Całkowity i czasowy zakaz reklamy dotyczącej otwartych funduszy emerytalnych spełnia tym samym warunek przydatności, według Trybunału Konstytucyjnego w rozumieniu art. 31 ust. 3 Konstytucji. Tak więc konstytucyjnym uzasadnieniem czasowego oraz całkowitego zakazu reklamy dotyczącej otwartych funduszy emerytalnych jest mianowicie urzeczywistnianie prawa ubezpieczonych do rzetelnej i pozbawionej warstwy sugestywnej informacji o systemie ubezpieczenia emerytalnego i skutkach podejmowanych decyzji w perspektywie przyszłego prawa do emerytury.

Jednakże uznanie całkowitego i czasowego zakazu reklamy dotyczącej OFE za służący realizacji wartości konstytucyjnych nie wystarcza, samo w sobie, do stwierdzenia jego zgodności z warunkiem niezbędności. Zgodnie z zasadami konstytucyjnymi rozwiązanie konieczne ma być najmniej dolegliwe, spośród wszystkich możliwych i równie skutecznych dostępnych rozwiązań, dla podmiotów, których wolności lub prawa są ograniczane. Takiego wymagania, zdaniem Trybunału, całkowity i czasowy zakaz reklamy nie spełnia.

Trybunał słusznie zauważył, że ustawodawca dysponuje innymi środkami prawnymi ochrony konsumentów, które są mniej dolegliwe niż całkowity i czasowy zakaz reklamy OFE. Przykładem takich regulacji są wymagania odnoszące się do treści i formy przekazywanych ubezpieczonym informacji przez otwarte fundusze emerytalne (art. 197 ustawy o o.f.f.e.). Przepisy te przewidują generalny nakaz informowania w sposób zrozumiały, obiektywny i rzetelny o sytuacji finan-

Ekonomia - Wroclaw Economic Review 22/2 (2016)

(C) for this edition by CNS 
sowej każdego otwartego funduszu emerytalnego lub powszechnego towarzystwa emerytalnego, a także ryzyku związanym z przystąpieniem do funduszu i pozostawaniem członkiem funduszu. Jednocześnie ustawa o o.f.f.e. przewiduje bezwarunkowy zakaz reklamy dotyczącej otwartego funduszu emerytalnego zawierającej informacje, które nie spełniają powyższych wymagań, lub wprowadzającej albo mogącej wprowadzić w błąd, który mógłby mieć wpływ na skłonienie kogokolwiek, aby przystąpił do otwartego funduszu lub w nim pozostawał. Dodatkowo do reklamy otwartych funduszy emerytalnych mają zastosowanie ogólne zakazy wynikające z przepisów ustawy o zwalczaniu nieuczciwej konkurencji (Dz.U. z 2003 r. Nr 153, poz. 1503). Zgodnie z art. 16 tejże ustawy czynem nieuczciwej konkurencji, stanowiącym zarazem wykroczenie, jest m.in. reklama sprzeczna z przepisami prawa, dobrymi obyczajami lub uchybiająca godności człowieka; reklama wprowadzająca klienta w błąd i mogąca przez to wpłynąć na jego decyzję co do nabycia towaru lub usługi; reklama odwołująca się do uczuć klientów przez wywoływanie lęku, wykorzystywanie przesądów lub łatwowierności dzieci; wypowiedź, która, zachęcając do nabywania towarów lub usług, sprawia wrażenie neutralnej informacji; reklama, która stanowi istotną ingerencję w sferę prywatności, w szczególności przez uciążliwe dla klientów nagabywanie w miejscach publicznych, przesyłanie na koszt klienta niezamówionych towarów lub nadużywanie technicznych środków przekazu informacji.

Trybunał słusznie zwrócił uwagę, że ustawodawca nie wykazał przekonująco, z jakich powodów powyższe obostrzenia i obowiązki informacyjne ciążące na OFE były niewystarczające do skutecznej ochrony wolności i praw ubezpieczonych w tzw. okresach transferowych. Tylko uprawdopodobnienie, że obowiązujące w systemie prawnym ogólne zakazy są nieskuteczne, mogło uzasadniać wprowadzenie dalej idącego środka, jakim jest całkowity zakaz reklamy od 1 stycznia do 31 lipca roku, w którym mogą być składane oświadczenia o dalszym wnoszeniu składki do OFE.

Ponadto o nadmierności czasowego i całkowitego zakazu reklamy OFE może świadczyć bardzo szeroki zakres zastosowania tego zakazu. Ustawodawca zakazał reklamy w każdej formie i za pomocą wszystkich nośników informacji, nie dokonując w tym względzie jakiegokolwiek niuansowania form lub intensywności rozpowszechniania wypowiedzi handlowych. Z punktu widzenia konstytucyjnego realizacja założonego celu mogła dokonać się przez ograniczenia tylko niektórych postaci reklamy bądź wymaganie zawarcia w przekazie określonych treści czy też limitowanie liczby emitowanych reklam.

Tymczasem całkowity zakaz reklamy odnoszącej się do OFE, obowiązujący w okresie od 1 stycznia do 31 lipca każdego roku, w którym ubezpieczeni mogą podejmować decyzję co do przekazywania części składki do OFE lub ZUS, czyli w okresach, w których przewidywane są największe transfery między funduszami, ogranicza możność konkurowania między samymi funduszami. Ustawodawca nie wyważył odpowiednio ciężaru ograniczenia z korzyściami płynącymi dla

Ekonomia - Wroclaw Economic Review 22/2 (2016)

(C) for this edition by CNS 
ubezpieczonych, ponieważ — w ostatecznym rozrachunku — również ubezpieczeni tracą możliwość uzyskania rzetelnej informacji o ofercie funduszy.

Nie bez znaczenia dla oceny konstytucyjności zupełnego czasowego zakazu reklamy OFE było także to, że obowiązuje on nie tylko w tzw. oknie transferowym (od 1 kwietnia do 31 lipca), czyli w okresie, w którym ubezpieczeni mogą składać oświadczenia o przekazywaniu do otwartego funduszu emerytalnego części składki emerytalnej lub zaewidencjonowaniu jej na subkoncie w ZUS. Zupełny czasowy zakaz reklamy OFE działa również przez trzy miesiące poprzedzające okres transferowy. Zdaniem Trybunału Konstytucyjnego tak daleko idące czasowo ograniczenie nie miało żadnego konstytucyjnego uzasadnienia. Dodatkowo - w tym zakresie — trudno uznać zakaz reklamy w okresie poprzedzającym okres transferowy za służący osiągnięciu celu, jakim jest ochrona ubezpieczonych oraz ich prawa do rzetelnej informacji o systemie ubezpieczeń społecznych, działających na rynku podmiotach czy ich ofercie. Ograniczenie to należałoby ponadto uznać za nadmierne dla podmiotów prywatnych działających w ramach drugiego filaru i współpracujących z nimi podmiotów, a ponadto niezbilansowane z korzyściami, jakie miałoby przynosić dla ubezpieczonych.

Z powyższych powodów Trybunał Konstytucyjny słusznie uznał, że czasowy całkowity zakaz reklamy OFE nie spełnia wymagania niezbędności, w rozumieniu art. 31 ust. 3 Konstytucji i jest z nią niezgodny. Wyrok Trybunału Konstytucyjnego wszedł w życie z dniem ogłoszenia w Dzienniku Ustaw, a jego następstwem było pozbawienie mocy obowiązującej niekonstytucyjnego przepisu (Wyrok Trybunału Konstytucyjnego 2015). Oznacza to, że z systemu prawa usunięty został czasowy całkowity zakaz reklamy OFE. Od tego momentu do informowania o działalności OFE, także w tzw. oknach transferowych, mają zastosowanie ogólne regulacje odnoszące się do informowania o działalności tych podmiotów.

\section{Skutki funkcjonowania czasowego całkowitego zakazu reklamy OFE}

Praktyka gospodarcza potwierdziła stanowisko Trybunału Konstytucyjnego o nadmierności czasowego całkowitego zakazu reklamy OFE. Zwolennicy tego zakazu w momencie jego wprowadzania argumentowali, iż jest on niezbędny, by ograniczyć liczbę ubezpieczonych, którzy zadeklarują dalsze przekazywanie części składki emerytalnej do otwartych funduszy emerytalnych.

Ich obawy wynikały z sukcesu kampanii reklamowej przeprowadzonej przez otwarte fundusze emerytalne i powszechne towarzystwa emerytalne na etapie wprowadzania reformy emerytalnej w 1999 roku, gdy urodzeni w latach 1949-1968 mieli rok czasu na podjęcie decyzji o przystąpieniu do otwartego funduszu emerytalnego lub pozostanie tylko i wyłącznie w pierwszym filarze ubezpieczenia emerytalnego. Z możliwości tej skorzystało wówczas ok. $60 \%$ ubezpieczonych. Na tej

Ekonomia - Wroclaw Economic Review 22/2 (2016)

(C) for this edition by CNS 
podstawie zwolennicy czasowego całkowitego zakazu reklamy OFE przyjęli założenie, że wprowadzenie tego zakazu ograniczy liczbę osób, które zdecydowałyby się na dalsze przekazywanie części składki emerytalnej do otwartych funduszy emerytalnych do $50 \%$ ubezpieczonych. Natomiast intensywna kampania reklamowa, analogiczna do kampanii przeprowadzonej w 1999 r., miała zniechęcić ubezpieczonych do subkonta w ZUS do tego stopnia, że aż około $80 \%$ ubezpieczonych miało zdecydować się na dalsze przekazywanie części składki emerytalnej do otwartych funduszy emerytalnych. To oznaczałoby dużo mniejsze środki trafiające na subkonta w ZUS i negatywnie odbijało się na wynikach Funduszu Ubezpieczeń Społecznych (Dybał, 2014). W tej sytuacji konieczne byłoby zwiększenie subsydiów dla FUS ze strony budżetu państwa, które rekompensowałyby ten ubytek. Niewątpliwie efekt ten nie miałby jednorazowego charakteru i konieczne byłoby dodatkowe i trwałe wspomaganie Funduszu Ubezpieczeń Społecznych ze strony budżetu państwa.

Tabela 1. Finansowe skutki braku czasowego i całkowitego zakazu reklamy OFE przy założeniu $80 \%$ partycypacji ubezpieczonych w przekazywaniu części składki emerytalnej do OFE

\begin{tabular}{l|r|r|r|r|r|r|r|r|r|r|r}
\hline & 2014 & 2015 & 2016 & 2017 & 2018 & 2019 & 2020 & 2021 & 2022 & 2023 \\
\hline \multicolumn{10}{c}{ Wpływ na sektor finansów publicznych } \\
\hline mld zł & 1,6 & 3,6 & 3,9 & 4,4 & 4,8 & 5,2 & 5,7 & 6,3 & 6,8 & 7,4 \\
\hline$\%$ PKB & 0,1 & 0,2 & 0,2 & 0,2 & 0,2 & 0,2 & 0,2 & 0,2 & 0,2 & 0,3 \\
\hline \multicolumn{10}{c}{ Wpływ na koszty obsługi długu } \\
\hline mld zł & 0 & 0,1 & 0,3 & 0,5 & 0,7 & 0,9 & 1,2 & 1,5 & 1,8 & 2,2 \\
\hline$\%$ PKB & 0 & 0 & 0 & 0 & 0 & 0 & 0 & 0,1 & 0,1 & 0,1 \\
\hline \multicolumn{10}{c}{ Wpływ na państwowy dług publiczny } \\
\hline mld zł & 1,7 & 5,4 & 9,4 & 13,9 & 18,3 & 23,6 & 29,3 & 35,6 & 42,4 & 49,7 \\
\hline$\%$ PKB & 0,1 & 0,3 & 0,5 & 0,7 & 0,8 & 1 & 1,2 & 1,3 & 1,5 & 1,7 \\
\hline
\end{tabular}

Wpływ na dług sektora instytucji rządowych i samorządowych

\begin{tabular}{l|r|r|r|r|r|r|r|r|r|r}
\hline mld zł & 1,7 & 5,4 & 9,4 & 13,9 & 18,3 & 23,6 & 29,3 & 35,6 & 42,4 & 49,7 \\
\hline$\%$ PKB & 0,1 & 0,3 & 0,5 & 0,7 & 0,8 & 1 & 1,2 & 1,3 & 1,5 & 1,7 \\
\hline
\end{tabular}

Źródło: Pismo Ministra Pracy i Polityki Społecznej DUS/-071/8/EW/CG/RM/14.

Tymczasem w praktyce, według stanu na koniec marca 2015 roku, zaledwie 15,1\% członków OFE złożyło oświadczenie o dalszym przekazywaniu części składki emerytalnej do OFE. Stanowi to około 2,5 mln osób. Warto dodać, że prawa do dalszego wnoszenia składek do OFE pozbawieni są najstarsi członkowie OFE. Składki ubezpieczonych, którzy osiągnęli wiek niższy niż 10 lat przed wiekiem emerytalnym, automatycznie kierowane są tylko na subkonto w ZUS (art. 22 ust. 3 w związku z art. 22 ust. $3 d$ ustawy o s.u.s.). Niewątpliwie tak zły rezultat dla otwartych funduszy emerytalnych jest wynikiem funkcjonowania czasowego całkowitego zakazu reklamy OFE w połączeniu z automatycznym kierowaniem całej kapita-

Ekonomia - Wroclaw Economic Review 22/2 (2016)

(C) for this edition by CNS 
łowej składki na subkonto w ZUS, gdy ubezpieczony nie złoży deklaracji o dalszym przekazywaniu składki na rachunek w $\mathrm{OFE}^{2}$. Zgodnie z przewidywaniami (Chybalski, 2013, s. 11-22) gwałtowny spadek liczby członków ma bezpośrednie przełożenie na liczbę składek odprowadzanych do otwartych funduszy emerytalnych (zob. tab. 2) i w konsekwencji wielkość aktywów netto tych funduszy (zob. tab. 3).

Tabela 2. Wysokość składek przekazanych w danym kwartale przez ZUS do OFE (PLN)

\begin{tabular}{|c|c|}
\hline Data & Kwota składek przekazanych w danym kwartale (PLN) \\
\hline $20091 \mathrm{kw}$ & 5015746293,57 \\
\hline $20092 \mathrm{kw}$ & 5811904205,82 \\
\hline $20093 \mathrm{kw}$ & 5515051970,18 \\
\hline $20094 \mathrm{kw}$ & 5175470007,28 \\
\hline $20101 \mathrm{kw}$ & 5857691618,09 \\
\hline $20102 \mathrm{kw}$ & 5919590437,59 \\
\hline $20103 \mathrm{kw}$ & 5819521390,53 \\
\hline $20104 \mathrm{kw}$ & 5561001100,10 \\
\hline $20111 \mathrm{kw}$ & 6470384446,03 \\
\hline $20112 \mathrm{kw}$ & 5083404023,41 \\
\hline $20113 \mathrm{kw}$ & 2204758483,75 \\
\hline $20114 \mathrm{kw}$ & 1993101350,75 \\
\hline $20121 \mathrm{kw}$ & 2252255958,89 \\
\hline $20122 \mathrm{kw}$ & 1806245906,33 \\
\hline $20123 \mathrm{kw}$ & 2152219673,81 \\
\hline $20124 \mathrm{kw}$ & 2199574465,39 \\
\hline $20131 \mathrm{kw}$ & 2526537335,43 \\
\hline $20132 \mathrm{kw}$ & 2224143903,09 \\
\hline $20133 \mathrm{kw}$ & 3998470552,14 \\
\hline $20134 \mathrm{kw}$ & 2305226862,00 \\
\hline $20141 \mathrm{kw}$ & 3175623838,23 \\
\hline $20142 \mathrm{kw}$ & 2893973024,67 \\
\hline $20143 \mathrm{kw}$ & 1512865180,84 \\
\hline $20144 \mathrm{kw}$ & 742846634,90 \\
\hline $20151 \mathrm{kw}$ & 817491744,68 \\
\hline
\end{tabular}

Źródło: opracowanie własne na podstawie Biuletynów Kwartalnych KNF — Rynek OFE.

2 Szerzej na temat wpływu zmian legislacyjnych w krajach Europy Środkowej i Wschodniej na liczbę członków funduszy emerytalnych oraz ilość i wielkość składek emerytalnych trafiających do kapitałowych części systemów emerytalnych patrz: F. Chybalski (2009), Liberalization of pension systems in Central and Eastern Europe, [w:] Funded part of Polish Pension System: Selected Problems, red. F. Chybalski, Łódź, s. 6-25.

Ekonomia - Wroclaw Economic Review 22/2 (2016)

(C) for this edition by CNS 
Może to być początek powolnego spadku wielkości aktywów netto otwartych funduszy emerytalnych w nadchodzącej przyszłości. Przed 2014 r. OFE dysponowały aktywami netto o wartości nawet ponad $300 \mathrm{mld}$ zł. Po raz pierwszy wartość aktywów netto OFE przekroczyła 300 mld 15 października 2013 roku, a historyczne maksimum odnotowano 25 listopada 2013 roku, kiedy w bilansach funduszy wykazano w tej pozycji $307 \mathrm{mld}$ zł (Banaszczak-Soroka, 2014).

Reforma kapitałowego filaru systemu emerytalnego i transfer ponad połowy aktywów OFE do ZUS fundamentalnie zmieniły wielkość aktywów OFE, co obrazuje tabela 3. Jednocześnie zmiany wprowadzone w 2014 r. rozpoczęly proces powolnego spadku wielkości aktywów netto OFE, oznaczający stopniowe i nieformalne wygaszanie kapitałowej części ubezpieczenia emerytalnego. Zmiany te są na tyle duże, że będą miały wpływ na adekwatność krajowego reżimu emerytalnego w długim okresie (Chybalski, 2011, s. 2-4).

Tabela 3. Aktywa netto OFE (PLN)

\begin{tabular}{l|c}
\hline \multicolumn{1}{c|}{ Data } & Aktywa netto OFE (PLN) \\
\hline 1999 & 2254837873,51 \\
\hline 2000 & 9921249691,37 \\
\hline 2001 & 19409420713,11 \\
\hline 2002 & 31564646669,65 \\
\hline 2003 & 44833088918,58 \\
\hline 2004 & 62626944016,05 \\
\hline 2005 & 86078777334,35 \\
\hline 2006 & 116563259565,10 \\
\hline X 2007 & 142800986642,69 \\
\hline 2007 & 140030893475,80 \\
\hline 2008 & 138261447317,79 \\
\hline II 2009 & 130867800968,77 \\
\hline 2009 & 178630090689,18 \\
\hline 2010 & 221251119982,00 \\
\hline 2011 & 224701817601,76 \\
\hline 2012 & 269596467329,15 \\
\hline 2013 & 299272473053,74 \\
\hline II 2014 & 153963070937,18 \\
\hline 2014 & 148450552223,89 \\
\hline VII 2015 & 155220056544,18 \\
\hline & 153721914609,98 \\
\hline 2015 & 19095969 \\
\hline 20
\end{tabular}

Źródło: opracowanie własne na podstawie Biuletynów Miesięcznych KNF — Rynek OFE.

Ekonomia - Wroclaw Economic Review 22/2 (2016)

(C) for this edition by CNS 
Od początku drugiego kwartału 2015 roku można zaobserwować systematyczny spadek wielkości aktywów netto otwartych funduszy emerytalnych, który jest dodatkowo pogłębiany przez korektę na krajowym rynku giełdowym.

\section{Zakończenie}

Zjawisko reklamy jest obecnie jednym z kluczowych elementów rynku, podstawową formą informowania o oferowanych towarach i świadczonych usługach, mającą skutkować zachęceniem klienta do nabycia dobra wytwarzanego przez konkretny podmiot. Stąd też ustanowienie czasowego całkowitego zakazu reklam OFE od samego początku budziło poważne zastrzeżenia. Zostały one potwierdzone wyrokiem Trybunału Konstytucyjnego, który zakaz ten uchylił. Niestety obowiązywanie czasowego całkowitego zakazu reklamy OFE w połączeniu z automatycznym kierowaniem całej kapitałowej składki na subkonto w ZUS, gdy ubezpieczony nie złoży odpowiedniej deklaracji o dalszym przekazywaniu składki na rachunek w OFE, przyczyniło się do dramatycznego spadku ilości wpłacanych składek do otwartych funduszy emerytalnych i rozpoczęło proces stopniowego i nieformalnego wygaszania kapitałowej części ubezpieczenia emerytalnego. Dlatego orzeczenie Trybunału Konstytucyjnego w zakresie czasowego całkowitego zakazu reklamy OFE może mieć decydujące znaczenie dla dalszego funkcjonowania rynku otwartych funduszy emerytalnych w Polsce. Zniesienie tego zakazu daje szanse na zahamowanie spadku liczby członków OFE oraz utrzymanie napływu składek do otwartych funduszy emerytalnych na dotychczasowym poziomie. To, czy otwarte fundusze emerytalne wykorzystają tę szansę, okaże się już w drugim kwartale 2016 roku.

\section{Bibliografia}

Chybalski F. (2009), Liberalization of pension systems in Central and Eastern Europe, [w:] Funded part of Polish Pension System: Selected Problems, red. F. Chybalski, Łódź.

Chybalski F. (2011), Adekwatność systemów emerytalnych wedtug celów OMC a reżimy emerytalne w Europie, „Polityka Społeczna”, Numer specjalny, część 1.

Chybalski F. (2013), Dobrowolność przynależności do OFE a dywersyfikacja ryzyka w systemie emerytalnym $w$ Polsce, [w:] Wspótczesne zabezpieczenie emerytalne, red. F. Chybalski, E. Marcinkiewicz, Łódź.

Dybał M. (2014a), Wpływ otwartych funduszy emerytalnych na deficyt budżetowy $i$ dtug publiczny, [w:] Instytucje prawnofinansowe w warunkach kryzysu gospodarczego, red. W. Miemiec, K. Sawicka, Warszawa.

Rynek otwartych funduszy emerytalnych w IV kwartale 2015 r., Urząd Komisji Nadzoru Finansowego, Warszawa 2016.

Rynki finansowe, red. U. Banaszczak-Soroka, Warszawa 2014.

Zawieja-Żurowska K. (2013), Refleksja nad przyszłościa systemu emerytalnego oraz finansowego bezpieczeństwa jego beneficjentów, [w:] Współczesne zabezpieczenie emerytalne. Wybrane aspekty ekonomiczne, finansowe i demograficzne, red. F. Chybalski, E. Marcinkiewicz, Łódź.

Ekonomia - Wroclaw Economic Review 22/2 (2016)

(C) for this edition by CNS 


\section{Źródła Prawa}

Konstytucja Rzeczypospolitej Polskiej z dnia 2 kwietnia 1997 r., Dz.U. z 1997 r. Nr 78, poz. 483. Opinia Ministra Pracy i Polityki Społecznej z dnia 4 marca 2014 w sprawie wniosku Prezydenta Rzeczypospolitej Polskiej z dnia 30 stycznia 2014 r. o zbadanie zgodności z Konstytucją RP niektórych przepisów ustawy z dnia 6 grudnia 2013 r. o zmianie niektórych ustaw w związku z określeniem zasad wypłaty emerytur ze środków zgromadzonych w otwartych funduszach emerytalnych.

Pismo Ministra Pracy i Polityki Społecznej z dnia 4 kwietnia 2014 r. (DUS/-071/8/EW /CG/RM/14) w sprawie wniosku Prezydenta RP z dnia 30 stycznia 2014. Ustawa z dnia 16 kwietnia 1993 r. o zwalczaniu nieuczciwej konkurencji, Dz.U. z 2003 r. Nr 153, poz. 1503 ze zm.

Ustawa z dnia 28 sierpnia 1997 r. o organizacji i funkcjonowaniu funduszy emerytalnych, Dz.U. z 2013 r., poz. 989.

Ustawa z dnia 13 października 1998 r. o systemie ubezpieczeń społecznych, tekst jedn. Dz.U. z 2009 r. $\mathrm{Nr} 205$, poz. 1585 ze zm.

Ustawa z dnia 25 marca 2011 r. o zmianie niektórych ustaw związanych z funkcjonowaniem systemu ubezpieczeń społecznych, Dz.U. z 2011 r. Nr 75, poz. 398, ze zm.

Ustawa z dnia 6 grudnia 2013 r. o zmianie niektórych ustaw w związku z określeniem zasad wypłaty emerytur ze środków zgromadzonych w otwartych funduszach emerytalnych, Dz.U. z 2013 r., poz. 1717.

Uzasadnienie projektu ustawy o zmianie niektórych ustaw w związku z określeniem zasad wypłaty emerytur ze środków zgromadzonych w otwartych funduszach emerytalnych z projektami aktów wykonawczych z dnia 22 listopada 2013 r. Druk nr 1946.

Wniosek Prezydenta Rzeczypospolitej Polskiej z dnia 30 stycznia 2014 r. (sygn. akt K 1/14) o zbadanie zgodności z Konstytucją RP niektórych przepisów ustawy z dnia 6 grudnia 2013 r. o zmianie niektórych ustaw w związku z określeniem zasad wypłaty emerytur ze środków zgromadzonych w otwartych funduszach emerytalnych (Dz.U. z 2013 r. poz. 1717).

Wniosek Rzecznika Praw Obywatelskich z dnia 29 sierpnia 2014 r. (sygn. akt K 1/14) o zbadanie zgodności z Konstytucją RP niektórych przepisów ustawy z dnia 6 grudnia 2013 r. o zmianie niektórych ustaw w związku z określeniem zasad wypłaty emerytur ze środków zgromadzonych w otwartych funduszach emerytalnych (Dz.U. z 2013 r., poz. 1717).

Wyjaśnienia Sejmu Rzeczypospolitej Polskiej z dnia 1 sierpnia 2014 (sygn. akt K 1/14) w sprawie wniosku Prezydenta RP z dnia 30 stycznia 2014.

Wyrok Trybunału Konstytucyjnego z dnia 4 listopada 2015 (sygn. akt K 1/14) (Dz.U. z 2015 r., poz. 1917).

Ekonomia - Wroclaw Economic Review 22/2 (2016)

(C) for this edition by CNS 